\title{
Closed Photobioreactor Assessments to Grow, Intensively, Light Dependent Microorganisms: A Twenty-Year Italian Outdoor Investigation
}

\author{
Pietro Carlozzi* \\ Istituto per lo Studio degli Ecosistemi, Distaccamento di Firenze, Consiglio Nazionale delle Ricerche, Polo Scientifico, \\ Via Madonna del Piano n. 10, 50019 Sesto F.no, Firenze, Italy
}

\begin{abstract}
Twenty years of Italian outdoor investigations on closed photobioreactors are discussed in this review. Many photobioreactor designs have been projected; some have been built, tested and patented. The Italian research approach from tubular (single tube and traditional loop) to flat and column and again to tubular photobioreactors (coil and loops) has improved microalgal yield. It increased from $25.0 \mathrm{gm}^{-2} \mathrm{~d}^{-1}$ in 1986 (using a traditional loop set down on the ground) to $47.7 \mathrm{gm}^{-2} \mathrm{~d}^{-1}$ in 2003, when results of a new tubular undulating row photobioreactor (TURP) were reported. This very high TURP productivity was attributed to a light dilution growth-strategy using Arthrospira platensis; the photic ratio $\left(\mathrm{R}_{\mathrm{f}}\right)$ ranged from 3 to 6 .
\end{abstract}

\section{INTRODUCTION}

From the 1950's on, many cultural systems have been designed and patented for the growing of photosynthetic microorganisms. At first, the aims of the researchers were to produce different types of biomass for the production of feed and food [1]. From these goals, applied technology first evolved towards open systems (ponds). They were cheap and required very simple technological assistance. The aims of the researchers changed as practical applications advanced. The main objective of microalgal biotechnology became the production of natural substances (antioxidants, bioactive molecules, polysaccharides, polymers, natural dyes and lipids etc.). Some chemicals that are extracted from microorganisms are often light dependent. Therefore, some chemical products can be obtained only through the photosynthetic process. The production of these natural products requires new and innovative types of technology such as closed systems that are able to control all physical and chemical parameters and to warrant high quality products. Biomasses achieved inside closed systems are free from any external contaminants. Since the 1980 's, intensive algal technology has begun to develop in closed systems, both in tubular photobioreactors [2-17] and in flat panel photobioreactors [1827]. Moreover, many airlift photobioreactors have been proposed for microalgal growth [28-32]. In 1995, a special instance of a column photobioreactor provided of some transparent plastic plates (horizontally situated in the cylinder and parallel to the bottom of the reactor) has been proposed to grow outdoors green algae as Scenedesmus and Chlorococcum [33]. This innovative photobioreactor was investigated again to use geothermal fluids and energy for mass microalgal cultivation as absorber tower [34, 35]. Recently, a peculiar new dome shaped photobioreactor, using aeration for mixing, has been investigated [36]. During the last few years, photobioreactor technology has been more and more

*Address correspondence to this author at the Istituto per lo Studio degli Ecosistemi, Distaccamento di Firenze, Consiglio Nazionale delle Ricerche, Polo Scientifico, Via Madonna del Piano n. 10, 50019 Sesto F.no, Firenze, Italy; E-mail: pietro.carlozzi@ise.cnr.it similar to that of 'fermentors'. The variety of bioprocesses is tremendous and many different designs of bioreactors have been developed to meet the different needs [37]. New technologies are necessary to dilute solar radiation and/or to improve light distribution in the culture thickness [38, 39]. One possible solution has been the use of optical fibers: when placed inside bioreactors they transmit visible solar rays that are condensed by fresnel lenses [19, 40]. For optical engineers to design light-redistributing plates with uniform radiation across the entire surface, the optical fibers were connected to the plates at the sides of a rectangular airlift bioreactor [41]. In 2003, for cultivation of microalgae under supra-high irradiance, a closed photobioreactor using collectors concentrating solar irradiance (linear Fresnel lenses) into the cultivation system has been proposed [42]. Finally, an innovative L-shape photobioreactor was investigated outdoors for single cell protein production; the pilot-scale photobioreactor used a scraper to mix Euglena culture a flow gas emitted from an industrial heater containing carbon dioxide, nitrogen oxide and sulphur oxide sources [43]. The new technologies are very sophisticated but more expensive than the traditional ones. They can be especially useful when microalgae, cyanobacteria, and photosynthetic bacteria are grown to produce pharmaceutical products. The creation of valuable pharmaceutical molecules and biotechnical energy considerations and are not usually relevant cost factors in economic analysis [44]. Some closed-systems such as polyethylene bags, fibreglass cylinders, flat plate reactors, and vertical columns [45-47] have been developed to cultivate marine microalgae (e.g. Isochrysis, Nannochloropsis, Chaetoceros etc.) as feed for fish, crustaceans and larval or juvenile stages of bivalves. In these closed systems, an air-sparger system must be placed at the bottom of the photobioreactor to allow for the mixing of the cultures and to avoid any dissolved oxygen build-up. Photobioreactors have been studied also to develop life support in space [48, 49]. In 2005, a technologically advanced photobioreactor, used for the growth and maintenance of a large number of microalgal strains was presented [50]. Finally some photobioreactors that use immobilized cells have been proposed in waste purification 
$[51,52]$. Over the years, many bioreactor designs have been proposed. However only those that deal with biomass production have been optimized [2, 6-8, 20, 21, 27, 53-55]. Peculiar substance syntheses such as those involving polysaccharides [3, 56, 57]; $\beta$-carotene [58-61]; lutein [62]; polyunsaturated fatty acids (PUFA) [63-68]; vitamins [69]; and/or biohydrogen [70] have not been taken into consideration for many years. In 2001, clean energy production (hydrogen) together with natural compounds (pigments and polymers) were able to be produced by purple bacteria cells (Rhodospirillaceae) grown inside an underwater tubular photobioreactor [71]. The aim of this review is to present the evolution of closed outdoor bioreactor systems in Italy since 1986. Designs and investigations by Italian researchers (under intensive conditions and controlling physical and chemical parameters) are described. An intensive approach consisting of cultivating mono-strains of photoautotrophic microorganisms in photobioreactors is more desirable than extensive ones that are largely uncontrollable with regard to production stability [72].

\section{TUBULAR PHOTOBOREACTORS}

Tubular photobioreactors are the oldest closed systems. They can be divided into the following categories: loop tubular photobioreactors; manifold tubular photobioreactors; coil photobioreactors and single tube photobioreactors.

\section{Loop Tubular Photobioreactors}

A study on the production of Spirulina biomass using outdoor culture in a tubular photobioreactor was presented in 1986 [73]. At first this apparatus was made up of flexible polyethylene transparent tubes $(14 \mathrm{~cm}$ diameter and $0.3 \mathrm{~mm}$ wall thickness), which were eventually replaced by Plexiglas tubes $(13 \mathrm{~cm}$ internal diameter (i.d.) and $4 \mathrm{~mm}$ wall thickness). The first photobioreactors consisted of several tubes placed side by side on a white polyethylene sheet: they were joined by polyvinyl chloride (PVC) U-bends to obtain a loop. A diaphragm pump system raised the culture to a feeding tank that contained a siphon and allowed for intermittent discharges of the culture into the photobioreactor. At intervals of $4.0 \mathrm{~min}$ an average culture volume of 3501 was discharged into the loop at a speed of $0.26 \mathrm{~ms}^{-1}$. The maximal length of the loop was $500 \mathrm{~m}$ and the volume was of $8.0 \mathrm{~m}^{3}$. The culture temperature and partial oxygen pressure were monitored: $\mathrm{pH}$ was maintained between 9.4 and 9.8 by $\mathrm{CO}_{2}$ addition. To avoid excessive culture temperature, three cooling systems were tested: shading tubes with dark-colored plastic sheets, the overlapping of two or three tubes and the cooling of the culture by spraying water on the surface of the tubes. This last one provided the best solution. Two biomass concentrations were tested $\left(0.6\right.$ and $\left.1.2 \mathrm{gl}^{-1}\right)$. In general the Spirulina culture grown at the low biomass concentration was more productive than the other was. Moreover a short loop of $250 \mathrm{~m}$ gave higher yields (about $25 \mathrm{gm}^{-2} \mathrm{~d}^{-1}$ in July) than the longer one $(500 \mathrm{~m})$. In 1987, another tubular photobioreactor $(150 \mathrm{~m}$ in length with a $7.4 \mathrm{~cm}$ internal diameter) was investigated: about $23 \mathrm{gm}^{-2} \mathrm{~d}^{-1}$ of Spirulina biomass yield was achieved [74].

\section{Multi-System Photobioreactors}

An outdoor-tubular multi-system equipped with instrumentation to control physical and chemical parameters was first described in [75]. This multi-system was composed of eight photobioreactors and four control cabins. It was built and assembled by Carlo Erba Instrumentation, Milan, (Italy) thanks to the financial resourcefulness of Prof. Gino Florenzano. Each single reactor consisted of a loop (20m long) made up of ten Pyrex glass tubes (i.d. $=4.85 \mathrm{~cm}$, length 2.0 $\mathrm{m})$ held together by PVC bend connections. The loop was placed horizontally in a stainless steel basin that contained thermostat-controlled demineralized water. A PVC pump, that used variable mechanical speeds, let the culture flow into the loop. At the end of the loop, the culture flowed into a cylindrical vessel. The speed of the culture could be changed from 0.2 to $0.5 \mathrm{~ms}^{-1}$ and the total culture volume was 501 . In 1986, this photobioreactor was tested using Spirulina platensis (strain M2) that had been grown with one of two different nitrogen sources (ammonia or nitrate). Under batch growth conditions, biomass dry weight (DW) accumulation, nitrogen uptake and lipid and carbohydrate biosyntheses were investigated; the major fatty acid Spirulina content was also investigated [75]. During the 1990's some investigations were carried out using this type of photobioreactor $[76,77]$. The effect of temperature on yield and night biomass losses in Spirulina platensis were studied at a culture temperature of $35^{\circ} \mathrm{C}$. The authors quoted a daylight biomass output rate of $0.52 \mathrm{~g}(\mathrm{DW}) \mathrm{1}^{-1} \mathrm{~d}^{-1}$ and $0.45 \mathrm{~g}(\mathrm{DW}) \mathrm{1}^{-1} \mathrm{~d}^{-1}$ over a 24 hour period. Productivity decreased to about $14 \%$ when Spirulina was grown at $25{ }^{\circ} \mathrm{C}$. In 1994, Spirulina photo-inhibition using the chlorophyll fluorescence technique was carried out [78]. During the same year, studies on the growth, physiology and nitrogenase activity of a nitrogen fixing cyanobacterium (Nodularia harveyana) took place [79]. In 1995, the chemical composition of Nodularia harveyana biomass was investigated and a yield of $13.2 \mathrm{~g}(\mathrm{DW}) \mathrm{m}^{-2} \mathrm{~d}^{-1}$ was reported [80]. Transient thermal analyses used to estimate solar radiation and to predict the Spirulina culture temperature within a reasonable degree of accuracy were carried out [81]. In this study, the authors achieved an average biomass yield of 23.7 $\mathrm{g}(\mathrm{DW}) \mathrm{m}^{-2} \mathrm{~d}^{-1}$, which corresponded to a volumetric productivity of $0.47 \mathrm{~g}(\mathrm{DW}) \mathrm{l}^{-1} \mathrm{~d}^{-1}$. In 1996 and 1998, experiments were carried out on light and oxygen stress in Spirulina platensis that had been grown at $35{ }^{\circ} \mathrm{C}[82,83]$. The authors reported a net biomass output rate of $0.52 \pm 0.20 \mathrm{~g}(\mathrm{DW}) \mathrm{l}^{-1} \mathrm{~d}^{-1}$ when the oxygen concentration within the Spirulina culture was $20.8 \pm 1.8 \mathrm{mgl}^{-1}$. In 1999 , studies on the changes in chlorophyll fluorescence quenching and the xanthophyll cycle in both Scenedesmus and Chlorella microalgae were undertaken [84]. The authors quoted biomass yields of 27.5 $\mathrm{g}(\mathrm{DW}) \mathrm{m}^{-2} \mathrm{~d}^{-1}$ and $21.5 \mathrm{~g}(\mathrm{DW}) \mathrm{m}^{-2} \mathrm{~d}^{-1}$ respectively in Scenedesmus quadricauda and Chlorella sorokiniana. In 2000, investigations on chlorophyll florescence quenching and the pigment composition of the green alga Chlorococcum sp. that had been grown under nitrogen deficiency were reported [85]: no data on productivity have yet been reported.

\section{Two-Plane Photobioreactor}

A two-plane tubular photobioreactor was tested in [6]; it was $245 \mathrm{~m}$ long and made of Plexiglas tubes (i.d. $=2.6 \mathrm{~cm}$, wall thickness $=2.0 \mathrm{~mm}$ ). The reactor volume was $145 \mathrm{l}$ : it covered an area of $7.8 \mathrm{~m}^{2}$. The culture was recycled in two different ways. One consisted of two airlift systems (one for each plane) and the other of two peristaltic pumps (one for each plane). The highest net productivity $\left(27.8 \mathrm{~g}(\mathrm{DW}) \mathrm{m}^{-2} \mathrm{~d}^{-1}\right)$ was reached when the photobioreactor was operated using 
the airlift system and solar radiation was $25.4 \mathrm{MJm}^{-2} \mathrm{~d}^{-1}$. Photosynthetic efficiency was $6.6 \%$ [6].

\section{Curved Tubular Photobioreactor}

In 1995, a new tubular photobioreactor was patented (Italian patent number: FI95A93) [86]. The curved tubular photobioreactor (CTP) was $67 \mathrm{~m}$ long with a working volume of 40 1: it was tested outdoors. It consisted of 128 Plexiglas tubes that are $0.3 \mathrm{~m}$ long (i.d. $=2.6 \mathrm{~cm}$, and a wall thickness $=2.0 \mathrm{~mm}$ ). These were connected by 127 glass U-bends so as to create a two-plane single loop (Fig. 1).

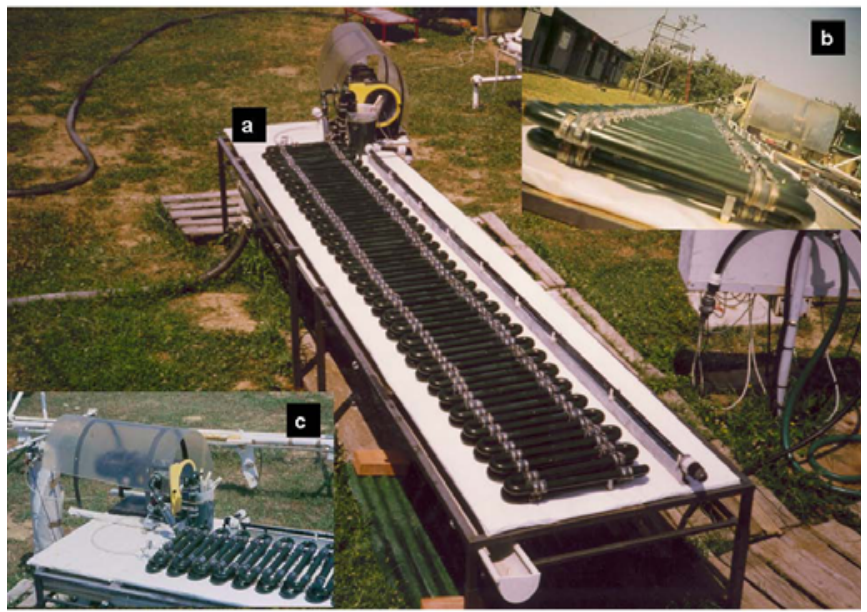

Fig. (1). Curved tubular photobioreactor (CTP) used outdoors to investigate productivity of Arthrospira platensis (ex Spirulina) grown from laminar to turbulent flow. (a) Global view of CTP: b, c details of CTP. The cultures were grown at an average biomass concentration of $10 \mathrm{gl}^{-1}$ dry weight.

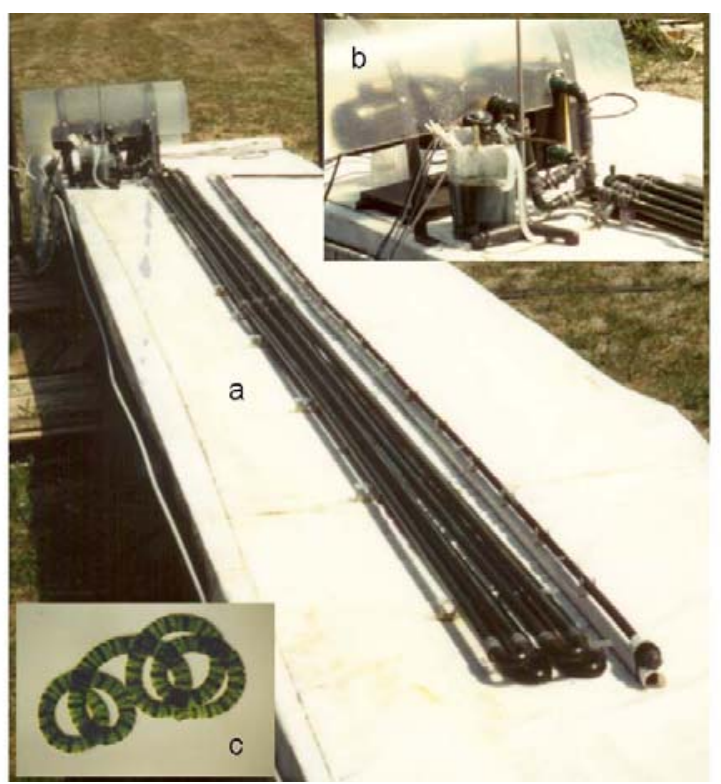

Fig. (2). Traditional loop photobioreactor used outdoors to investigate Arthrospira productivity grown from laminar to turbulent flow. (a) Global view of the loop; (b) pump system; (c) an Arthrospira platensis trichome.
The CTP was tested using Spirulina platensis that had been grown at a very high cell concentration of $10.0 \mathrm{~g}(\mathrm{DW}) \mathrm{l}^{-1}$ [9]. A peristaltic pump recycled the culture: the recycling speed ranged from 0.18 to $0.97 \mathrm{~ms}^{-1}$. At the optimal speed of $0.75 \mathrm{~ms}^{-1}$ the highest net productivity $\left(1.19 \mathrm{~g}(\mathrm{DW}) \mathrm{l}^{-1} \mathrm{~d}^{-1}\right.$ corresponding to $\left.23.8 \mathrm{~g}(\mathrm{DW}) \mathrm{m}^{-2} \mathrm{~d}^{-1}\right)$ was achieved. Productivity decreased when the speed of the culture was lower or higher than the optimal velocity [9]. The effect of a convective flow on Spirulina productivity was also investigated. Productivity was compared with a typical loop photobioreactor (Fig. 2). The Spirulina yield was always lower in the traditional loop than that obtained in the CTP.

\section{Tubular Undulating Row Photobioreactor}

Since 1995 a new tubular photobioreactor design (an evolution of Italian patent no. FI95A93) has been studied. Originally, it was built and tested near Florence (Scandicci), Italy. The tubular undulating row photobioreactor (TURP) was characterized by five rows, each of which is $1.0 \mathrm{~m}$ long and $0.22 \mathrm{~m}$ high. Each row was made of a PVC flexible transparent tube $22.0 \mathrm{~m}$ long (i.d. $=1.0 \mathrm{~cm}$ and the wall thickness $=2.0 \mathrm{~mm}$ ). The tubes were arranged in a sinusoidal shape (Fig. 3). The culture entered through the lowest tubes and came out of the top tubes of the rows, where a Plexiglas chamber of the airlift system raises the culture up to a degasser. Five down-flow PVC tubes connected the degasser with the lowest tubes of each row; compressed air was injected into the Plexiglas chamber by a perforated tube that is level with the tube unions. This allowed for the circulation of the culture through the TURP. Other details concerning the design of the TURP can be found in the literature $[38,39]$. Two types of TURPs were tested: one covered a surface area of $1.0 \mathrm{~m}^{2}$ (TURP-5r) and the other, $0.5 \mathrm{~m}^{2}$ (TURP-10r). Performance of the two regarding both hydrodynamic aspects and Arthrospira growth are still being investigated. Culture lamination and the creation of vertical reactor configurations allowed for obtaining solar light dilution [39].
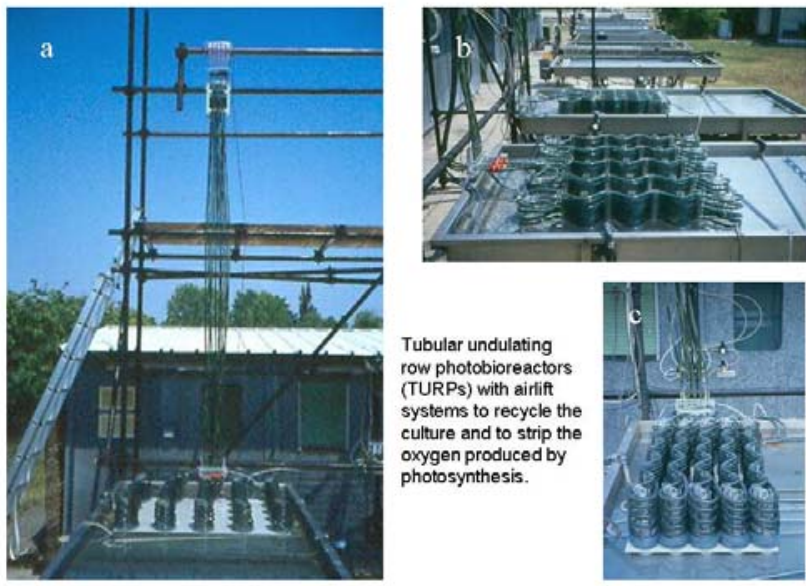

Fig. (3). Tubular undulating row photobioreactors (TURPs) equipped with airlift systems to recycle the culture and to strip the oxygen produced by photosynthesis. (a, c) Front view; (b) side view.

The whirling of the culture was investigated in [38]. The shear factor values, as a function of the Reynolds number, were obtained experimentally in a $22 \mathrm{~m}$ long PVC straight tube with an internal diameter of $10 \mathrm{~mm}$. In the TURP-10r, 
in the rows that were facing east-west, net Arthrospira productivity was $34.4 \pm 1.2 \mathrm{~g}(\mathrm{DW}) \mathrm{m}^{-2} \mathrm{~d}^{-1}$; it was achieved when solar radiation was $24.26 \pm 1.53 \mathrm{MJm}^{-2} \mathrm{~d}^{-1}$ [38]. A study on light dilution strategy of solar radiation through culture lamination and the photic ratio $\left(\mathrm{R}_{\mathrm{f}}\right)$ in this reactor type was carried out in [39]. The light intensity intercepted by a vertical flat surface on a typical summer day was reported using south-north facing, and east-west facing: the values were compared with that intercepted by a horizontal flat surface. A very high net Arthrospira productivity of $47.7 \mathrm{~g}(\mathrm{DW}) \mathrm{m}^{-2} \mathrm{~d}^{-}$ ${ }^{1}$ had been attained when the reactor was operated at a daily dilution rate of $0.3 \mathrm{~d}^{-1}$ [39]. In 2005, using the same reactor type, the rheological behavior of the Arthrospira culture using low to high cell concentrations (from 2.0 to $20.5 \mathrm{gl}^{-1}$ ) [87] was investigated. A study on the hydrodynamic aspects of the Arthrospira culture was carried out and the rheological behavior of Zarrouk's medium was compared with tap water. The power consumed $\left(\mathrm{P}_{\mathrm{c}}\right)$ in a single row for $\mathrm{Ar}$ throspira culture recycling at different generalized Reynolds numbers was reported. It was demonstrated that power consumption increases as a function of both cell concentration and the generalized Reynolds number. The energy requirement for recycling algal culture in tubes (i.e. with the TURPs working at a generalized Reynolds number of 2345) was investigated. The power consumed at the cell concentration of $2.0 \mathrm{gl}^{-1}$ was only $7.8 \%$ of the maximum power $\left(\mathrm{P}_{\max }\right)$; at a cell concentration of $8.0 \mathrm{gl}^{-1} . \mathrm{P}_{\mathrm{c}}$ was about $80 \% \mathrm{P}_{\max }$ and at a cell concentration of $11.1 \mathrm{gl}^{-1}$, the $\mathrm{P}_{\mathrm{c}}$ was $100 \% \mathrm{P}_{\max }$ [87].

\section{Anoxic Underwater Tubular Photobioreactor}

An underwater tubular photobioreactor (UwTP) (Fig. 4), used to grow photosynthetic bacteria under anaerobic growth conditions, was investigated [71]. It was similar to the one described in the literature [75]. However, in 2001, the reactor was tested for the first time under anoxic conditions: Rhodopseudomonas palustris growth was studied outdoors. Experiments were carried out for six months to investigate photosynthetic efficiency, daily pigment fluctuations, poly- $\beta$ hydroxybutyrate (PHB) and carbohydrate syntheses in the light. Moreover, it was demonstrated that PHB and the carbohydrates were partially consumed in the dark. The achievable biomass output rate using the system, which had been operating at optimal cell concentration $\left(1.0 \mathrm{gl}^{-1}\right)$ was determined from low to high solar radiation $(5.07 \pm 3.0$ to $23.09 \pm$ $\left.2.4 \mathrm{MJm}^{-2} \mathrm{~d}^{-1}\right)$. In summer, when solar radiation reached the maximum value, the highest yield obtained in the UwTP was $64.1 \pm 9.8 \mathrm{~g}(\mathrm{DW})$ reactor $^{-1} \mathrm{~d}^{-1}$. On the contrary, the highest photosynthetic efficiency of $7.6 \%$ was achieved in winter. Recently, another study was carried out using this anoxic photobioreactor to investigate the growth kinetics of Rhodopseudomonas palustris [88]. In summer photosynthetic efficiency changes in changing daylight were also investigated. Remarkable changes in photosynthetic efficiency values were attained. under natural and forced light/dark cycles, the photosynthetic efficiency trends were always oscillatory with the exception of that achieved at a low biomass concentration $\left(0.65 \mathrm{gl}^{-1}\right)$. The lowest photosynthetic efficiency $(2.4 \%)$ was achieved at noon and the highest $(11.2 \%)$ at sunset.

\section{Manifold Tubular Photobioreactors}

In 1998, a nearly horizontal tubular reactor (manifold tubular photobioreactor) was investigated [10]. The photo- bioreactor consisted of five $6.0 \mathrm{~m}$ long Plexiglas tubes (i.d. $=$ $3.4 \mathrm{~cm}$; wall thickness $=0.3 \mathrm{~cm}$ ). The tubes were connected at the bottom and at the top by tubular Plexiglas manifolds. The photobioreactor was placed on a wooden framework facing south and tilted to form a $5^{\circ}$ horizontal angle. In summer, the volumetric productivity of Arthrospira achieved in this reactor was of $1.26 \pm 0.05 \mathrm{~g}(\mathrm{DW}) \mathrm{l}^{-1} \mathrm{~d}^{-1}$ and the photosynthetic efficiency was $5.6 \pm 0.2 \%$. In 1998 , a nearly horizontal tubular photobioreactor (installed in Hawaii) with a slop of between $6-12 \%$ was tested for hydrogen production [89]. The reactor consisted of eight $20 \mathrm{~m}$ long tubes connected at the bottom to a manifold (including an airlift system to recycle the culture) and at the top to a degasser. Some other manifold tubular photobioreactors of different flexible plastic-tube dimensions and lengths (i.d. $=0.043 \mathrm{~m} / 6.4 \mathrm{~m}$, $11.0 \mathrm{~m}$ and $44.0 \mathrm{~m}$ ) have been used to produce eicosapentaenoic acid using Nannochloropsis sp. The highest Nannochloropsis biomass output rate of $0.60 \pm 0.23 \mathrm{~g}(\mathrm{DW}) \mathrm{l}^{-1} \mathrm{~d}^{-1}$ was achieved [67].

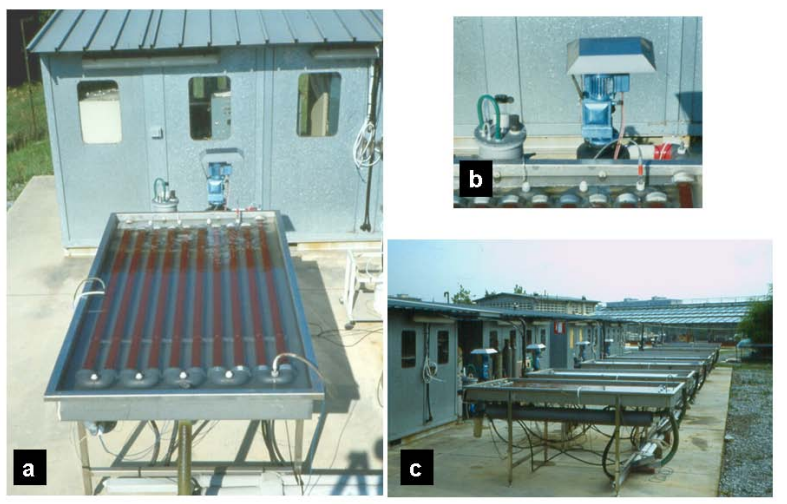

Fig. (4). (a) Underwater tubular photobioreactor (UwTP); (b) pump system for culture recycling; (c) global view of plant.

\section{Coil Tubular Photobioreactors}

A helical bubble reactor was investigated outdoors in [10]. The coil tubular photobioreactor was made up of three $49 \mathrm{~m}$ long PVC tubes. The tubes had a $3.0 \mathrm{~cm}$ internal diameter, and were rolled around a metallic vertical structure $(1.1 \mathrm{~m}$ diameter). The highest ends of the tubes were connected to a degasser. The culture flowed down through a single pipe from the degasser. Air was injected at the bottom of each tube to allow for the mixing of the culture, to strip the oxygen produced by cyanobacterial (Arthrospira) growth and to prevent bio fouling. The bubbles flowed up to the degasser before escaping from the culture. Culture cooling was achieved by water spraying. This reactor had a total volume of 1201 . With this system, Arthrospira productivity of 0.9 $\mathrm{g}(\mathrm{DW}) \mathrm{l}^{-1} \mathrm{~d}^{-1}$ was achieved. The authors reported a photosynthetic efficiency of $6.6 \%$. In 1996, Inalco S.p.A. near Florence, Italy built another coil tubular photobioreactor with a total volume of about $3000 \mathrm{l}$. No data on this coil have so far been reported [90]. A new closed coil photobioreactor (CCP) that had an incorporated mandrel to control culture temperature was designed and patented in 1995 (Fig. 5) (Italian patent number: FI95A92) [91]. The configuration was chosen to avoid random mixing of the culture (due to a turbulent flow) and to guarantee a regular mixing pattern that is generated 
during fluid recycling by a secondary flow in a curved tube [92]. It was made up of two flexible $40 \mathrm{~m}$ long PVC tubes (i.d. $=1.0 \mathrm{~cm}$, wall thickness $=2.0 \mathrm{~mm}$ ) rolled around the mandrel with a diameter of $4.8 \mathrm{~cm}$ to create a CCP of $6.0 \mathrm{~m}$ in length. Recycling of the culture was carried out using either a peristaltic pump or an airlift system. When $A r-$ throspira was grown under batch conditions and recycled with the pump system, a very high cell concentration was achieved (16.4 $\left.\mathrm{g}(\mathrm{DW}) \mathrm{l}^{-1}\right)$ [92]. Some hydrodynamic aspects such as the required power for culture recycling inside the $\mathrm{CCP}$ and the reactor cycle time as a function of Dean number were investigated. When the pump recycled the culture, a very high Dean number was achieved $\left(D_{e}=3950\right)$. The Dean number decreased in a remarkable way when the pump was replaced with the airlift system $\left(D_{\mathrm{e}}=1800\right)$. Using the airlift system, under semi-continuous Arthrospira growth, a photosynthetic efficiency of $7.4 \%$ was achieved. The gross biomass output rate was $2.85 \mathrm{~g}(\mathrm{DW}) \mathrm{l}^{-1} \mathrm{~d}^{-1}$; the net reduced to $2.32 \pm 0.11 \mathrm{~g}(\mathrm{DW}) \mathrm{l}^{-1} \mathrm{~d}^{-1}$. When the pump was used to recycle the culture the biomass output rate decreased: the gross was $2.61 \mathrm{~g}(\mathrm{DW}) \mathrm{l}^{-1} \mathrm{~d}^{-1}$; the net was $1.79 \mathrm{~g}(\mathrm{DW}) \mathrm{l}^{-1} \mathrm{~d}^{-1}$. The authors attributed the better performance attained using the airlift system to a low concentration of oxygen build up within the culture $\left(\leq 20 \mathrm{mgl}^{-1}\right)$ and the lack of cell damage. Both experiments were carried out on an average starting cell concentration of $4.0 \mathrm{gl}^{-1}$. There are some advantages when using the new reactor (CCP) as regards outdoor microalgal growth. One is the regulation of the culture temperature. It is possible to warm the culture during the first lighted hours of the morning (when culture temperature is below optimal) and cool the culture temperature during the day, when it could reach too high values. It limits oxygen buildup within the culture and avoids mechanical cell damage, verified when using the pump [92]. Moreover, the multi-airlift system is very cheap to run.

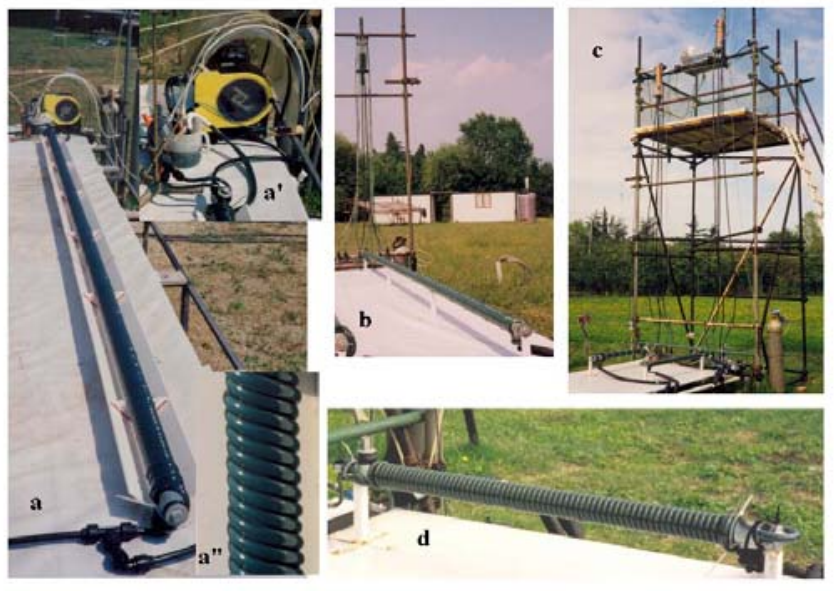

Fig. (5). Close coil photobioreactor (CCP) incorporating a mandrel to control culture temperature. (a) CCP equipped with a pump system for culture recycling; (b,c,d) CCP equipped with an airlift system for culture recycling.

\section{Single Tube Photobioreactors}

In 1986, a single-tube wide-diameter photobioreactor $\left(\mathrm{STP}_{\mathrm{WD}}\right)$ was tested under anoxic conditions to grow Rhodopseudomonas palustris [93]. An average productivity of 43 $\mathrm{g}(\mathrm{DW}) \mathrm{m}^{-2} \mathrm{~d}^{-1}$ (calculated on the basis of the occupied area) was reported by the authors. The reactor consisted of a Plexiglas tube $10.0 \mathrm{~m}$ long (i.d. $=0.4 \mathrm{~m}$ ) with a working volume of $1.25 \mathrm{~m}^{3}$. The $\mathrm{STP}_{\mathrm{WD}}$ was immerged in a water bath (Fig. 6). The culture in this reactor was mixed by an internal system, formed by two ring-shaped brushes, with three spokes each, connected to a rigid plastic pipe. The internal system was moved by a wire rope connected to a spool which had both take-up and delivery functions. A motor positioned on the top of the reactor moved the spool. A rope sheave was positioned opposite the spool. Its perpendicular axis of rotation was locked at the top and at the bottom of the reactor. Two switching devices positioned at both extremities of the photobioreactor (backwards and forwards) attained traction of the ring-shaped brushes. A complete cycle of the ring-shaped brush traction consisted of going backwards and forwards. The culture mixing was discontinuous: there were intervals of 15 minutes (controlled by a timer). Three cycles for each mix input were imposed. The aims of this mixing system were to mix the culture and to clean up the wall of the bioreactor.

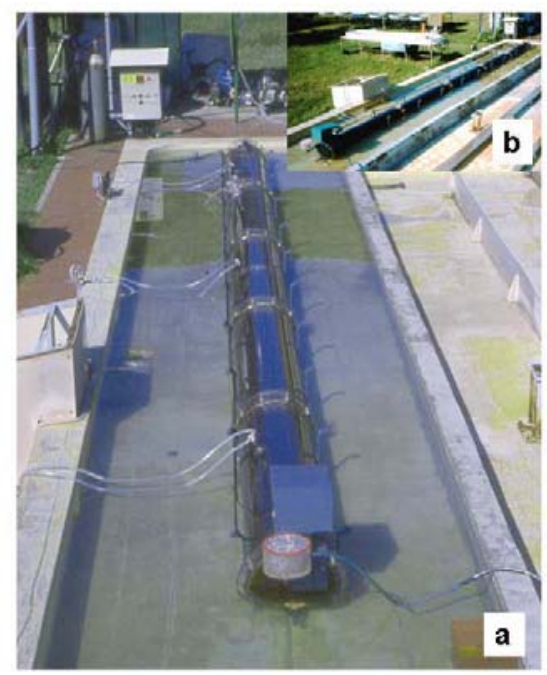

Fig. (6). Single tube photobioreactor of wide diameter $\left(\mathrm{STP}_{\mathrm{WD}}\right)$ equipped with an internal system to mix the culture. The reactor consists of a Plexiglas tube $10.0 \mathrm{~m}$ long (i.d. $=0.4 \mathrm{~m}$ ) with a working volume of $1.25 \mathrm{~m}^{3}$.

In 1996 , another single tube reactor $(50 \mathrm{~mm}$ external diameter; $1.5 \mathrm{~mm}$ wall thickness and $6.2 \mathrm{~m}$ long) was tested [94]. The tube was placed on a platform facing south and tilted to form a horizontal angle of $10^{\circ}$. Arthrospira cells were grown inside this oxygenic reactor type. The culture was mixed by compressed air injection at the bottom of the tube. In July, 1996, the highest productivity achieved in this single tube reactor was $1.05 \pm 0.14 \mathrm{~g}(\mathrm{DW}) 1^{-1} \mathrm{~d}^{-1}$.

\section{VERTICAL OR INCLINED FLAT PANELS}

In 1990, several vertical alveolar panel (VAP) reactors, with a surface area of $0.5-2.2 \mathrm{~m}^{2}$, were constructed from $1.6 \mathrm{~cm}$ thick Plexiglas alveolar sheets [21] (Fig. 7). VAPs were filled with a culture suspension leaving a space of 4.0 $5.0 \mathrm{~cm}$ from the top of the panel: culture thickness was 1.25 $\mathrm{cm}$. The photobioreactors were placed facing south with an inclination of $25^{\circ}$ (angle subtended with the horizontal); the 
inclination was changed monthly in order to maximize the amount of radiant energy received by the reactor surface. Both the mixing of the cultures and the stripping of oxygen produced by the photosynthetic process were achieved by bubbling compressed air at the bottom of the reactors at a mean flow rate of 0.5 to $1.011_{\text {culture }^{-1}}$. The culture $\mathrm{pH}$ was controlled by the addition of $\mathrm{CO}_{2}$ (from a cylinder) to the airflow. In winter, culture temperature was maintained at 30 $\pm 1.5^{\circ} \mathrm{C}$ during the daytime. At night, it was $20 \pm 1.5^{\circ} \mathrm{C}$. During the summer, the night culture temperature was not regulated. In September, $\left(\right.$ solar radiation $=16.6 \mathrm{MJm}^{-2} \mathrm{~d}^{-1}$ ) the highest gross Spirulina productivity was $23.9 \mathrm{~g}(\mathrm{DW}) \mathrm{m}^{-}$ ${ }^{2} \mathrm{~d}^{-1}$ : its net value was reduced to $15.8 \mathrm{~g}(\mathrm{DW}) \mathrm{m}^{-2} \mathrm{~d}^{-1}$. During the summer (solar radiation $=23.0 \mathrm{MJm}^{-2} \mathrm{~d}^{-1}$ ) Anabaena azollae was cultured inside the VAP. The highest gross Anabaena azollae productivity was $16.0 \mathrm{~g}(\mathrm{DW}) \mathrm{m}^{-2} \mathrm{~d}^{-1}$, which was reduced to a net value of $11.0 \mathrm{~g}(\mathrm{DW}) \mathrm{m}^{-2} \mathrm{~d}^{-1}[21]$.
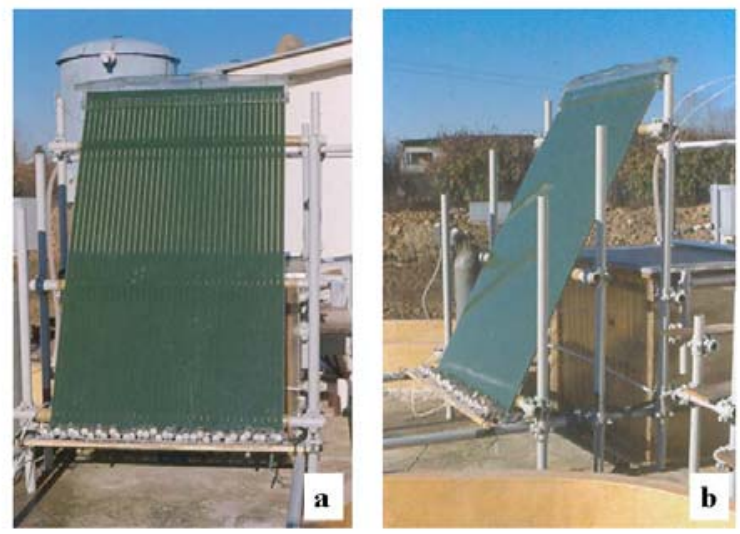

Fig. (7). Alveolar panel bioreactor design built to investigate Spirulina platensis growth outdoors. (a) Front view; (b) side view.

In 1992, different airflow rates in relation to productivity were investigated. Gross Spirulina productivity achieved in the VAP was $30.2 \mathrm{~g}(\mathrm{DW}) \mathrm{m}^{-2} \mathrm{~d}^{-1}$, while the net dropped to $23.5 \mathrm{~g}(\mathrm{DW}) \mathrm{m}^{-2} \mathrm{~d}^{-1}$. To obtain these results, the reactor was operated with a maximum airflow rate of $1.2111_{\text {culture }^{-1}}$ [95]. The highest net average Spirulina productivity was 24.0 $\mathrm{g}(\mathrm{DW}) \mathrm{m}^{-2} \mathrm{~d}^{-1}$ with the VAP [96]. In 1998 results concerning a near-horizontal flat panel were reported [10]. The system consisted of a rectangular chamber $(6.05 \mathrm{~m}$ long; $0.2 \mathrm{~m}$ wide and $0.025 \mathrm{~m}$ thick) divided longitudinally into five inner channels. Experiments were carried out with Arthrospira platensis (strain M2). The authors reported a daily reactor productivity of $31.61 \pm 1.74 \mathrm{~g}(\mathrm{DW}) \mathrm{R}^{-1} \mathrm{~d}^{-1}$. Since the reactor cross-sectional area was $1.3 \mathrm{~m}^{2}$, the Arthrospira biomass yield calculated on the basis of this area was $24.3 \mathrm{~g}(\mathrm{DW}) \mathrm{m}^{-}$ ${ }^{2} \mathrm{~d}^{-1}$. In 2004, a green wall reactor was patented [97]. The reactor design consisted of flexible transparent plastic film contained in a rigid metal framework so as to form a relatively thin vertical panel. The biggest reactor module experimented on outdoors (volume $=640 \mathrm{l}$ ) was $1.0 \mathrm{~m}$ high, $10.0 \mathrm{~m}$ long and $5.0 \mathrm{~cm}$ wide. The photobioreactor was tested to cultivate several microalgae used in aquaculture. Productivity ranged from 0.15 to $1.0 \mathrm{~g}(\mathrm{DW}) \mathrm{l}^{-1} \mathrm{~d}^{-1}[98]$.

\section{VERTICAL COLUMNS}

In 2002, a vertical annular reactor was developed at the University of Florence, Italy to produce Nannochloropsis biomass for hatchery feed. It was made up of two $2.0 \mathrm{~m}$ high Plexiglas cylinders. A cylinder with a narrower diameter was placed inside a wider one. Both were closed at the bottom thus obtaining an annular chamber. In 2003, some results using this reactor shape were published [99]. Two vertical annular reactors with different outer diameters $(50 \mathrm{~cm}$ and 91 $\mathrm{cm})$ were investigated. The smaller reactor had a volume of $120 \mathrm{l}$, a culture thickness of $4.5 \mathrm{~cm}$ and an illuminated surface area of $5.3 \mathrm{~m}^{2}$. The larger one had a volume of 1401 , a culture thickness of $3.0 \mathrm{~cm}$ and an illuminated surface area of $9.3 \mathrm{~m}^{2}$. Culture mixing, $\mathrm{pH}$ regulation and gas-exchanges were obtained by injecting a mixture of air and $\mathrm{CO}_{2}$ at various points at the bottom of the annular chamber. Under artificial illumination with a metal halide lamp the highest productivity (34.0 $\mathrm{g}(\mathrm{DW})$ reactor $\left.^{-1} 24 \mathrm{~h}^{-1}\right)$ was achieved in the reactor with the $91 \mathrm{~cm}$ outer diameter; under natural light (in May). Productivity was $34.1 \mathrm{~g}(\mathrm{DW})$ reactor $^{-1} 24 \mathrm{~h}^{-1}$. During combined illumination under green house conditions (400 metal halide lamps for the internal annular surface and natural illumination on the annular external surface) reactor productivity increased to $48.3 \mathrm{~g}(\mathrm{DW})$ reactor $^{-1} 24 \mathrm{~h}^{-1}$. Similar results were also reported in [100]. More recently outdoor experiments were carried out by Tredici's group [101]. Tetraselmis suecica growth was investigated in annular columns for both productivity and photosynthetic efficiency. Isolated column productivity was compared with a simulated fullscale column (arranged in the triangular way) [101]. There were no significant differences between the average productivity of the two arrangements $\left(0.49 \mathrm{gl}^{-1} \mathrm{~d}^{-1}\right.$ and $0.46 \mathrm{gl}^{-1} \mathrm{~d}^{-1}$ respectively). Moreover, on sunny days (average solar radiation of $23.0 \mathrm{MJm}^{-2} \mathrm{~d}^{-1}$ ) the photosynthetic efficiency that had been determined for the whole experimental period was $9.1 \%$ and area productivity was $38.7 \mathrm{gm}^{-2} \mathrm{~d}^{-1}$.

\section{CONCLUSIONS}

This review focuses on twenty years of Italian research and technological advances on closed photobioreactors that are used to grow photosynthetic microorganisms. Light dependent microorganisms are utilized to produce a great variety of metabolites: natural dyes; vitamins; antioxidants; PUFAs; polysaccharides; and some new bioactive molecules for the pharmaceutical and cosmetic industries. Photosynthetic microbic biomasses are also used to obtain human food and animal feed (aquaculture). Many photobioreactor shapes have been evaluated experimentally: each one has some peculiarity. The curved tubular photobioreactor is better than the traditional loop type to increase biomass output rate [9]. The two-plane photobioreactor produces higher biomass yield than does the single-plane photobioreactor [6]. The coiled reactor types are good for realising the right exposition of cells to a light dark cycle thanks to the curvature radius of the coil and the good surface-to-volume ratio $[8,92]$. Airlift and/or bubble column photobioreactors are adequate systems to grow microalgae. Unfortunately, their main drawback is the limitation of the availability of light. They are also limited as regards large-scale systems: poor light penetration is a serious problem, when cells grow in highdensity cultures [102]. A solution to overcome this drawback 
is the employment of optical fibers. The absorber tower [35], the L-shape [43] and the dome [36] photobioreactors are quite interesting for their new configurations. However, further studies are needed to better understand the conditions for their best performances. Flat panels are another photobioreactor group. They require compressed air, injected at the bottom of the panel, to mix the culture and to remove oxygen produced by the photosynthetic process. Flat panels together with annular columns and airlift photobioreactor types allow for 'soft' culture mixing to grow microalgal species, which are very sensitive to high-shear (e.g. Dunaliella, Hematococcus, Porphyridium). Many studies have also been carried out on the effects of culture agitation, airflow rate, bubble dimensions and gas entrance velocity at the sparger [11, 103-105]. Tubular photobioreactors have been the most studied systems during the twenty-year Italian experience in the field. The performance of this reactor type has improved a great deal. The yield has increased from $25.0 \mathrm{gm}^{-2} \mathrm{~d}^{-1} \mathrm{ob}-$ tained in 1986, using the traditional loop placed on the ground [73], to $47.7 \mathrm{gm}^{-2} \mathrm{~d}^{-1}$ when a new tubular undulating row photobioreactor was tested [39]. This very high productivity (1.9 times higher than the first value reported in 1986) has been attributed to the possibility of the TURP to dilute solar radiation. The TURP design has allowed for culture lamination, and a high surface-volume ratio $\left(400 \mathrm{~m}^{-1}\right.$ - The highest value reported in Italy). Dilution of solar radiation is very important for the growing of microalgae, outdoors. Culture lamination permits an increase in the surface-to-volume ratio: this is a desirable characteristic if one is to reach an efficient utilisation of solar radiation for biomass production [39]. Our high biomass yield may have been attained thanks to the culture lamination strategy (Fig. 8). In Fig. (8) the relationship between culture lamination and the surface-tovolume ratio $(\mathrm{S} / \mathrm{V})$ concept is explained graphically. A thin flat panel is an optimal example of 'culture' lamina. A reactor arrangement in thin layers can produce very high photobioreactor performance levels. In Fig. (8), letters B, C, D, and $\mathrm{E}$ are examples of a growing trend in reactor lamination. The thickness of the reactor layers has changed from $0.1 \mathrm{~m}$ in (B) to $0.01 \mathrm{~m}$ in (E). The illuminated surface-to-volume ratio $\left(\mathrm{S}_{\mathrm{ill}} / \mathrm{V}\right)$ has increased from $5.0 \mathrm{~m}^{-1}$ in $(\mathrm{A})$ [in a nonlaminated reactor (A)] to $23 \mathrm{~m}^{-1}$ in (B) and from $43 \mathrm{~m}^{-1}$ in (C) to $83 \mathrm{~m}^{-1}$ in (D) and $203 \mathrm{~m}^{-1}$ in (E). Tubular row photobioreactors, flat panels and, annular columns, which are panels that have been arranged in a cylindrical shape, are able to achieve both a high surface-to-volume ratio and high photic ratio $\left(R_{f}\right)$ values. $R_{f}$ is the relationship between the illuminated surface $\left(\mathrm{S}_{\text {ill }}\right)$ and the occupied surface $\left(\mathrm{S}_{\text {occ }}\right)$ of the photobioreactor [38]:

$$
\mathrm{R}_{\mathrm{f}}=\mathrm{S}_{\mathrm{ill}} / \mathrm{S}_{\text {occ }}
$$

when the occupied surface of the reactor-system contains two or more thin culture layers (panels or loop rows) the equation is the following:

$$
\mathrm{R}_{\mathrm{f}}=\mathrm{S}_{\mathrm{ill}} \cdot \mathrm{nR} / \mathrm{S}_{\mathrm{occ}}
$$

where $n R$ is the number of rows and/or panels [39].

When the occupied surface of the reactor-system contains two or more columns or other photobioreactor shapes, the equation is the following:

$$
\mathrm{R}_{\mathrm{f}}=\mathrm{S}_{\mathrm{ill}} \cdot \mathrm{nPBRs} / \mathrm{S}_{\text {occ }}
$$

where nPBRs is the number of columns or other photobioreactor shapes. We achieved the highest biomass yield using the tubular undulating row photobioreactor. This reactor offers many advantages when compared with other photobioreactors. We can control the liquid flow rate with high precision and induce secondary circulation in a cross-section of the curved tube. We can control the light-dark cycle frequency by a sine wave motion of the algal culture and improve the light distribution in the culture thus leading to better light utilisation. We can manage the photic ratio by the spacing or closing of the rows [38, 39].

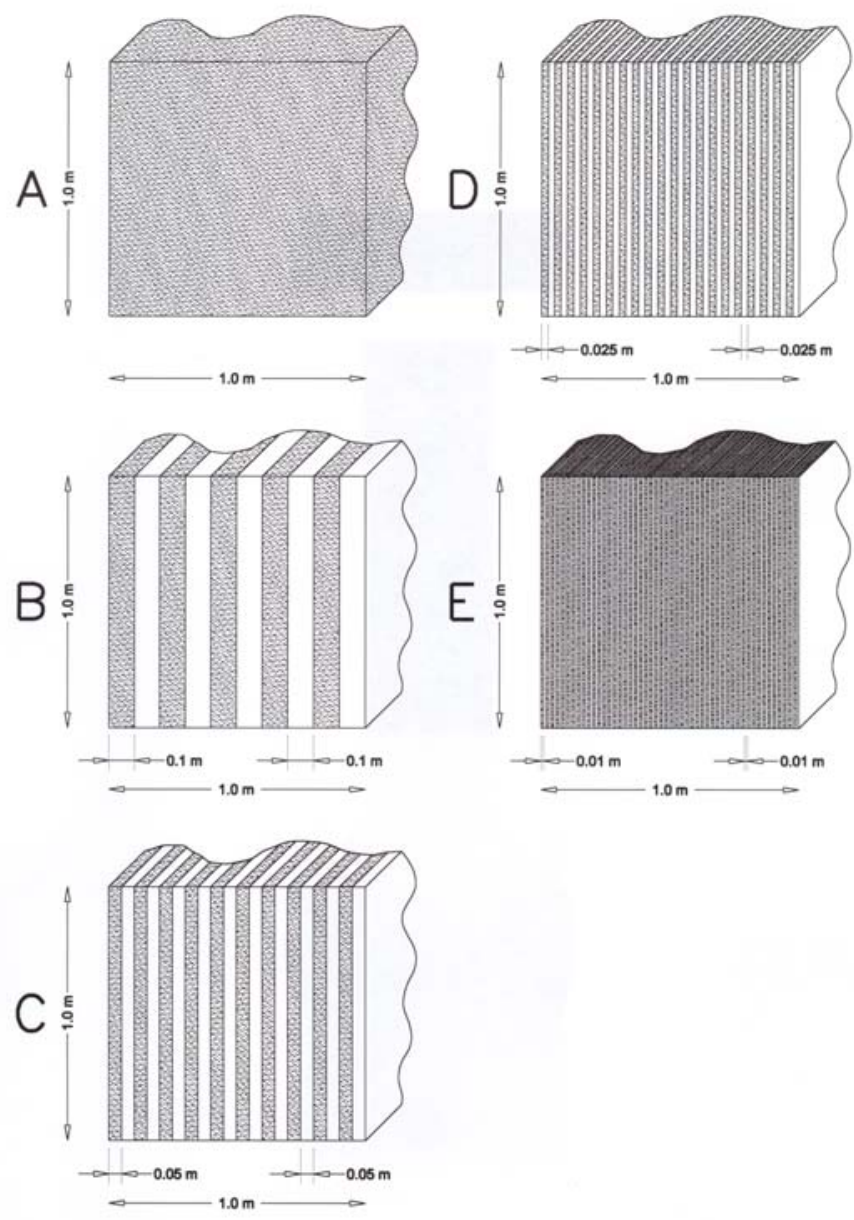

Fig. (8). Culture lamination concept. (A) A non-laminated reactor; (B), (C), (D) and (E) are examples of growing reactor lamination, where the thickness of the reactor layers changes from $0.1 \mathrm{~m}$ in (B) till $0.01 \mathrm{~m}$ in $(\mathrm{E})$. The volume of the reactors is the following: $\mathrm{V}=$ $1.0 \mathrm{~m}^{3}$ in (A) and $\mathrm{V}=0.5 \mathrm{~m}^{3}$ in $\mathrm{B}, \mathrm{C}, \mathrm{D}, \mathrm{E}$. In order to calculate $\mathrm{V}$ values, the wall thickness of each layer was considered to be infinitesimal.

Higher productivity than that achieved in Italy has been reported in Malaya [7] and in Israel [24, 25]. In 2006, Tredici's group approached a productivity level of $39.0 \mathrm{gm}^{-}$ ${ }^{2} \mathrm{~d}^{-1}$ by growing Tetraselmis suecica in annular columns [101]. That result was possible thanks to the relatively high photic ratio $\left(\mathrm{R}_{\mathrm{f}}=3.65\right)$ realised with a simulation of a fullscale column (68 columns- $\left.100 \mathrm{~m}^{-2}\right)$. Personal calculations were carried out using the data quoted by Tredici's group in [101], which were inserted in Eq. 3. Algal production systems need to be further improved in order to become com- 
petitive and more economically feasible. Future research should focus on the improvement of production systems and on the genetic modification of existing strains [106]. Scaledup models of small scale TURPs [38, 39] could be used to increase chemical and biomass production. The row configuration of this type of photobioreactor permits dilution of solar radiation, which is very important if the light oversaturation point is to be avoided. Microalgal cells should be kept under low light intensity during natural bright illumination. A big photobioreactor plant $\left(700 \mathrm{~m}^{3}\right)$ installed in Germany consists of vertically arranged horizontal running glass tubes (rows), which produce significant quantities of Chlorella biomass (130-150 t(DW)year $\left.{ }^{-1}\right)[106,107]$.

\section{REFERENCES}

[1] Belay A, Kato T, Ota Y. Spirulina (Arthrospira): potential application as an animal feed supplement. J Appl Phycol 1996; 8: 303-11.

[2] Pirt SJ, Lee YK, Walach MR, et al. A tubular bioreactor for photosynthetic production of biomass from carbon dioxide: design and performance. J Chem Biotechnol 1983; 33: 35-58.

[3] Gudin C, Thepenier C, Chaumont D, et al. In: Ramus J, Jones MC, Eds. Polysaccharides from Microalgae. Beaufort, Duke University Marine Laboratory. 1988; 133-41.

[4] Borowitzka LJ, Borowitzka MA. In: Cresswell RC, Rees TAV, Shah N, Eds. Algal and cyanobacteria biotechnology. New York, Longman/Wiley. 1989; 294-16.

[5] Lee ETY, Bazin MJ. A laboratory scale air-lift helical photobioreactor to increase biomass output rate of photosynthetic algal cultures. New Phytol 1990; 116: 331-35.

[6] Torzillo G, Carlozzi P, Pushparaj B, et al. A two-plane tubular photobioreactor for outdoor culture of Spirulina. Biotechnol Bioeng 1993; 42: 891-8.

[7] Lee YK, Ding SY, Low CS, et al. Design and performance of a $\alpha$ type tubular photobioreactor for mass cultivation of microalgae. $J$ Appl Phycol 1995; 7: 47-51.

[8] Watanabe Y, De la Noüe J, Hall DO. Photosynthetic performance of a helical tubular photobioreactor incorporating the cyanobacterium Spirulina platensis. Biotechnol Bioeng 1995; 47(2): 261-9.

[9] Carlozzi P, Torzillo G. Productivity of Spirulina in a strongly curved outdoor tubular photobioreactor. Appl Microbiol Biotechnol 1996; 45: 18-23.

[10] Tredici MR, Chini Zittelli G. Efficiency of sunlight utilization: tubular versus flat photobioreactors. Biotechnol Bioeng 1998; 57(2): 187- 97.

[11] Gudin C, Chaumont D. Cell fragility - The key problem of microalgae mass production in closed photobioreactors. Biores Technol 1991; 38: 145- 51

[12] Lee YK, Low CS. Effect of photobioreactor inclination on the biomass productivity of an outdoor algal culture. Biotechnol Bioeng 1991; 38: 995- 00.

[13] Richmond A, Boussiba S, Vonshak A, et al. A new tubular reactor for mass production of microalgae outdoors. J Appl Phycol 1993; 5: 327-32.

[14] Morita M, Watanabe Y, Okawa T, et al. Photosynthetic productivity of conical helical tubular photobioreactors incorporating Chlorella $s p$. under various culture medium flow conditions. Biotechnol Bioeng 2001; 74(2): 136-44.

[15] Fernández FGA, Hall DO, Guerrero EC, et al. Outdoor production of Phaeodactylum tricornutum biomass in a helical reactor. J Biotechnol 2003; 103: 137-52.

[16] Muller-Feuga A, Pruvost J, Le Guédes R, et al. Swirling flow implementation in a photobioreactor for batch and continuous cultures of Porphyridium cruentum. Biotechnol Bioeng 2003; 84: 544-51.

[17] Sandnes JM, Ringstad T, Wenner D, et al. Real-time monitoring and automatic density control of large-scale microalgal cultures using near infrared (NIR) optical density sensors. J Biotechnol 2006; 122: $209-15$

[18] Samson R, Leduy A. Multistage continuous cultivation of bluegreen alga Spirulina maxima in the flat tank photobioreactors. Can J Chem Eng 1985; 63: 105-12.

[19] Mori K. Photoautotrophic bioreactor using visible solar rays condensed by fresnel lenses and transmitted through optical fibers. Biotechnol Bioeng Symp 1985; 15: 331-45.
[20] Ramos de Ortega A, Roux JC. Production of Chlorella biomass in different types of flat bioreactors in temperate zones. Biomass 1986; 10: 141-56.

[21] Tredici MR, Carlozzi P, Chini Zittelli G, et al. A vertical alveolar panel (VAP) for outdoor mass cultivation of microalgae and cyanobacteria. Biores Technol 1991; 38: 153-9.

[22] Pulz O. Cultivation techniques for microalgae in open and closed systems. Paper presented at the 1st European Workshop on Microalgal Biotechnology, Potsdam - Rehbrücke, June 10-12, 1992.

[23] Pulz O, Gerbsch N, Buchholz R. Light energy supply in plate-type and light diffusing optical fiber bioreactors. J Appl Phycol 1995; 7: 145-9.

[24] Hu Q, Guterman H, Richmond A. A flat inclined modular photobioreactor for outdoor mass cultivation of photoautotrophs. Biotechnol Bioeng 1996; 51: 51-60.

[25] Richmond A, Hu Q. Principles for efficient utilization of light for mass production of photoautotrophic microorganisms. Appl Biochem Biotechnol 1997; 63/65: 649-58.

[26] Richmond A, Zou Q. Efficient utilization of high photon irradiance for mass production of photoautotrophic microorganisms. J Appl Phycol 1999; 11: 123-7.

[27] Zhang K, Kurano N, Miyachi S. Outdoor culture of cyanobacterium with a vertical flat-plate photobioreactor: effects on productivity of the reactor orientation, distance setting between the plates, and culture temperature. Appl Microbiol Biotechnol 1999; 52: 7816.

[28] Chisti Y, Moo-Young M. Improve the performance of airlift reactors. Chem Eng Prog 1993; 89(6): 38-45.

[29] Vernerey A, Albiol J, Lasseur C, et al. Scale-up and design of a pilot-plant photobioreactor for the continuous culture of Spirulina platensis. Biotechnol Prog 2001; 17: 431-8.

[30] Zhang X, Zhou B, Zhang Y, et al. A simple and low-cost airlift photobioreactor for microalgal mass culture. Biotechnol Lett 2002; 24: $1767-71$.

[31] Mirón AS, García MCC, Camacho FG, et al. Mixing in bubble and airlift reactors. Chem Eng Res Part 2004; 82(a10): 1367-74.

[32] Li ZY, Guo SY, Li L, Cai MY. Effects of electromagnetic field on the batch cultivation and nutritional composition of Spirulina platensis in an air-lift photobioreactor. Bioresour Technol 2007; 98: $700-5$.

[33] Petkov GD, Muchtarova MG. Heat balance of a closed microalgal photoreactor. Arch Hydrobiol 1995; 79: 119-24.

[34] Fournadzieva S, Petkov G, Pilarski P, et al. Use of geothermal fluids and energy for mass microalgal cultivation. Paper presented at the International Course on Geothermal Energy, Klamath Falls, October 10-16, 1999.

[35] Petkov GD. Absorber tower as a photobioreactor for microalgae. Russ J Plant Physiol 2000; 46(6): 786-8.

[36] Sato T, Usui S, Tsuchiya Y, et al. Invention of outdoor closed type photobioreactor for microalgae. Energy Convers Manage 2006; 47: 791-9.

[37] Chisti Y, Moo-Young M. In: Meyers R, Ed. Encyclopedia of Physical Science and Technology. San Diego, Academic Press, 2001; 2: 247-71.

[38] Carlozzi P. Hydrodynamic aspects and Arthrospira growth in two outdoor tubular undulating row photobioreactors. Appl Microbial Biotechnol 2000; 54: 14-22.

[39] Carlozzi P. Dilution of solar radiation through "culture" lamination in photobioreactor rows facing south north: a way to improve the efficiency of light utilization by cyanobacteria (Arthrospira platensis). Biotechnol Bioeng 2003; 81: 305-15.

[40] Ogbonna JC, Soejima T, Tanaka H. An integrated solar and artificial light system for internal illumination of photobioreactors. J Biotechnol 1999; 70: 289-97.

[41] Janssen M, Tramper J, Mur LR, et al. Enclosed outdoor photobioreactors: light regime, photosynthetic efficiency, scale-up, and future prospects. Biotechnol Bioeng 2003; 81: 193-210.

[42] Masojídek J, Papáček Š, Sergejevová M, et al. A closed solar photobioreactor for cultivation of microalgae under supra-high irradiance: basic design and performance. J Appl Phycol 2003; 15: 23948.

[43] Chae SR, Hwang EJ, Shin HS. Single cell protein production of Euglena gracilis and carbon dioxide fixation in an innovative photo-bioreactor. Biores Technol 2006; 97: 322-9. 
[44] Luque S, Mallubhotla H, Gehlert G, et al. A new coiled hollowfiber module design for enhanced microfiltration performance in biotechnology. Biotechnol Bioeng 1999; 65(3): 247-57.

[45] Renaud SM, Parry DL, Thinh LV, et al. Effect of light intensity on the proximate biochemical and fatty acid composition of Isochrysis $s p$. and Nannochloropsis oculata for use in tropical aquaculture. $\mathrm{J}$ Appl Phycol 1991; 3(1): 43-54.

[46] Cheng-Wu Z, Zmora O, Kopel R, et al. An industrial-size flat plate glass reactor for mass production of Nannochloropsis $s p$. (eustigmatophyceae). Aquaculture 2001; 195: 35-49.

[47] Krichnavaruk S, Loataweesup W, Powtongsook S, et al. Optimal growth conditions and the cultivation of Chaetoceros calcitrans in airlift photobioreactor. Chem Eng J 2005; 105: 91-8.

[48] Gòdia F, Albiol J, Montesinos JL, et al. Melissa: a loop of interconnected bioreactors to develop life support in space. J Biotechnol 2002; 99: 319- 30.

[49] Wang G, Chen H, Li G, et al. Population growth and physiological characteristics of microalgae in a miniaturized bioreactor during space flight. Acta Astronautica 2006; 58: 264-9.

[50] Nowack ECM, Pondola B, Melkonian M. The 96-well twin-layer system: a novel approach in the cultivation of microalgae. Protist 2005; 156: 239- 51.

[51] Vincenzini M, Balloni W, Mannelli D, et al. A bioreactor for continuous treatment of wastewater with immobilized cells of photosynthetic bacteria. Experientia 1981; 37: 710-1.

[52] Yun SI, Ohta Y. Removal of volatile fatty acids with immobilized Rhodococcus sp. B621. Bioresour Technol 2005; 96: 41-6.

[53] Burlew JS. In: Burlew JS, Ed. Algal culture from laboratory to pilot plant. Washington, Carnegie Institution. 1953; 3-23.

[54] Pulz O. Open-air and semi-closed cultivation systems for the mass cultivation of micro-algae. Paper presented at the $1^{\text {st }}$ Asia-Pacific Conference on Algal Biotechnology, Kuala Lumpur, January 2126, 1992.

[55] Richmond A. Efficient utilization of high irradiance for production of photoautotrophic cell mass: a survey. J Appl Phycol 1996; 8: 381-7.

[56] Andersen DW, Eakin DE. A process for the production of polysaccharides from microalgae. Biotechnol Bioeng Symp 1985; 15: 53347.

[57] You T, Barnett SM. Effect of light quality on production of extracellular polysaccharides and growth rate of Porphyridium cruentum. Biochem Eng J 2004; 19: 251-8.

[58] Olaizola M. Commercial production of astaxanthin from Haematococcus pluvialis using 25,000-liter outdoor photobioreactors. J Appl Phycol 2000; 12: 499-506.

[59] Hejazi MA, Wijffels RH. Effect of light intensity on $\beta$-carotene production and extraction by Dunaliella salina in two-phase bioreactors. Biomol Eng 2003; 20: 171-5.

[60] García-González M, Moreno J, Manzano JC, et al. Production of Dunaliella salina biomass rich in 9-cis- $\beta$-carotene and lutein in a closed tubular photobioreactor. J Biotechnol 2005; 115: 81-90.

[61] García-Malea López MC, Del Río Sánchez E, Casas López JL, et al. Comparative analysis of the outdoor culture of Haematococcus pluvialis in tubular and bubble column photobioreactors. J Biotechnol 2006; 123: 329-42.

[62] Del Campo JA, Rodríguez H, Moreno J, et al. Lutein production by Muriellopsis $s p$. in an outdoor tubular photobioreactor. J Biotechnol 2001; 85: 289-95.

[63] Yongmanitchai W, Ward OP. Growth of and omega-3 fatty acid production by Phaeodactylum tricornutum under different culture conditions. Appl Environ Microbiol 1991; 57: 419-25.

[64] Molina Grima E, Sánchez Perez JA, Garcia Camacho F, et al. Effect of growth rate on the eicosapentaenoic acid and docosahenaenoic acid content of Isochrysis galbana in chemostat culture. Appl Microbiol Biotechnol 1994; 41: 23-7.

[65] Qiang H, Zhengyu H, Cohen Z, et al. Enhancement of eicosapentaenoic acid (EPA) and $\gamma$-linolenic acid (GLA) production by manipulating algal density of outdoor cultures of Monodus subterraneus (eustigmatophyta) and Spirulina platensis (cyanobacteria). Eur J Phycol 1997; 32: 81-6.

[66] Otero A, Garcia D, Morales ED, et al. Manipulation of the biochemical composition of the eicosapentaenoic acids-rich microalga Isochrysis galbana in semicontinuous cultures. Biotechnol Appl Biochem 1997; 26: 171-7.
[67] Chini Zittelli G, Lavista F, Bastianini A, et al. Production of eicosapentaenoic acid by Nannochloropsis sp. cultures in outdoor tubular photobioreactors. J Biotechnol 1999; 70: 299-312.

[68] Wen ZY, Chen F. Heterotrophic production of eicosapentaenoic acid by microalgae. Biotechnol Adv 2003; 21: 273-94.

[69] Carballo-Cardenas EC, Tuan PM, Janssen M, et al. Vitamin e ( $\alpha-$ tocopherol) production by the marine microalgae Dunaliella tertiolecta and Tetraselmis suecica in batch cultivation. Biomol Eng 2003; 20: 139-47.

[70] Zaborsky OR, Beneman J, Matsunaga T, et al. Biohydrogen: 1998: Proceedings of an International Conference on Biological Hydrogen Production; 1998 June 23-26; Waikoloa, Hawaii. Plenum Press: a division of Plenum Publishing Corporation, University of Hawaii; 1998.

[71] Carlozzi P, Sacchi A. Biomass production and studies on Rhodopseudomonas palustris grown in an outdoor, temperature controlled, underwater tubular photobioreactor. J Biotechnol 2001; 88: 239-49.

[72] Belkacemi K, Hamoudi S. Photobioreactor stability by phase plane technique applied to Spirulina maxima growth. Int J Chem React Eng 2003; 1: 1-19.

[73] Torzillo G, Pushparaj B, Bocci F, et al. Production of Spirulina biomass in closed photobioreactors. Biomass 1986; 11: 61-74.

[74] Torzillo G, Bocci F, Pushparaj B, et al. Studies on the production of Spirulina biomass through outdoor culture in tubular photobioreactor. Paper presented at the 4th International Conference on Biomass for Energy and Industry, Orléans, May 11-15, 1987.

[75] Bocci F, Torzillo G, Vincenzini M, et al. Growth physiology of Spirulina platensis in tubular photobioreactor under natural light. Paper presented at the $4^{\text {th }}$ International Meeting on Algal Biotechnology of the SAA, Villeneuve d'Ascq, September 15-17, 1987.

[76] Torzillo G, Sacchi A, Materassi R. Temperature as an important factor and night biomass loss in Spirulina platensis grown outdoors in tubular photobioreactors. Bioresour Technol 1991; 38: 95-00.

[77] Torzillo G, Sacchi A, Materassi R, et al. Effect of temperature on yield and night biomass loss in Spirulina platensis grown outdoors in tubular photobioreactor. J Appl Phycol 1991; 3: 103-9.

[78] Vonshak A, Torzillo G, Tomaselli L. Use of chlorophyll fluorescence to estimate the effect of photoinhibition in outdoor cultures of Spirulina platensis. J Appl Phycol 1994; 6: 31-4.

[79] Pushparaj B, Pelosi E, Torzillo G, et al. Growth physiology of a marine nitrogen-fixing cyanobacterium (Nodularia harveyana) in outdoor culture. J Appl Phycol 1994; 6: 533-7.

[80] Pushparaj B, Pelosi E, Carlozzi P, et al. Yield and biochemical composition of a marine cyanobacterium (Nodularia sp.) in outdoor culture. Aquat Microb Ecol 1995; 9: 13-6.

[81] Prakash J, Torzillo G, Pushparaj B, et al. Transient analysis and performance studies of two tubular photobioreactors for outdoor culture of Spirulina. Int J Ener Res 1995; 19: 479-91.

[82] Vonshak A, Torzillo G, Accolla P, et al. Light and oxygen stress in Spirulina platensis (cyanobacteria) grown outdoors in tubular reactors. Physiol Plant 1996; 97: 175-9.

[83] Torzillo G, Bernardini P, Masojídek J. On-line monitoring of chlorophyll fluorescence to assess the extent of photoinhibition of photosynthesis induced by high oxygen concentration and low temperature and its effect on the productivity of outdoor cultures of Spirulina platensis (cyanobacteria). J Phycol 1998; 34: 504-10.

[84] Masojídek J, Torzillo G, Koblížek M, et al. Photoadaptation of two members of the chlorophyta (Scenedesmus and Chlorella) in laboratory and outdoor cultures: changes in chlorophyll fluorescence quenching and the xanthophyll cycle. Planta 1999; 209: 126-35.

[85] Masojídek J, Torzillo G, Kopecký J, et al. Changes in chlorophyll fluorescence quenching and pigment composition in the green alga Chlorococcum sp. grown under nitrogen deficiency and salinity stress. J Appl Phycol 2000; 12: 417-26.

[86] Carlozzi P, Torzillo G, Materassi R, inventori; Consiglio Nazionale delle Ricerche, mandatario. Fotobioreattore con circolazione della massa colturale in condotti offrenti curvature successive e sostanzialmente inverse. Italian patent IT FI95A93. Maggio 1995.

[87] Carlozzi P, Ena A, Carnevale S. Hydrodynamic alterations during cyanobacteria (Arthrospira platensis) growth from low to high biomass concentration inside tubular photobioreactors. Biotechnol Progr 2005; 21: 416-22.

[88] Carlozzi P, Pushparaj B, Degl'Innocenti A, et al. Growth characteristics of Rhodopseudomonas palustris cultured outdoors, in an underwater tubular photobioreactor, and investigation on photosynthetic efficiency. Appl Microbiol Biotechnol 2006; 73: 789-95. 
[89] Tredici MR, Chini Zittelli G, Beneman J. A tubular integral gas exchange photobioreactor for biological hydrogen production. $\mathrm{Pa}-$ per presented at the International Conference on Biological Hydrogen Production, Waikoloa, June 23-26, 1997.

[90] Tredici MR. In: Flickinger MC, Drew SW, Eds. Encyclopedia of Bioprocess Technology: Fermentation, Biocatalysis and Bioseparation. J Wiley \& Sons, 1999; 1: 395-419.

[91] Carlozzi P, Torzillo G, Materassi R, inventori; Consiglio Nazionale delle Ricerche, mandatario. Fotobioreattore con circolazione della massa colturale in un condotto sostanzialmente elicoidale. Italian patent IT FI95A92. Maggio 1995.

[92] Carlozzi P, Pinzani E. Growth characteristics of Arthrospira platensis cultured inside a new close-coil photobioreactor incorporating a mandrel to control culture temperature. Biotechnol Bioeng 2005; 90(6): 675-84.

[93] Balloni W, Carlozzi P, Ventura S, et al. A three years experiment on the production of Rhodopseudomonas and Rhodospirillum biomass by outdoor culture of different wastes. Paper presented at the 4th International Conference on Biomass for Energy and Industry, Orléans, May 11-15, 1987.

[94] Chini Zittelli G, Tomasello V, Pinzani E, et al. Outdoor cultivation of Arthrospira platensis autumn and winter in temperature climates. J Appl Phycol 1996; 8: 293-301.

[95] Tredici MR, Zittelli GC, Biagiolini S. Influence of turbulence and areal density on the productivity of Spirulina platensis grown outdoor in a vertical alveolar panel. Paper presented at the 1st European Workshop on Microalgal Biotechnology, Potsdam Rehbrücke, June 10-12, 1992.

[96] Tredici MR. In: Richmond A, Ed. Handbook of Microalgal Culture. Oxford, UK, Blackwell Science LTD; Ames, USA, Blackwell Publishing Company. 2004; 178-214.
[97] Tredici MR, Rodolfi L, inventors; Università degli Studi di Firenze, assignee. Reactor for industrial culture of photosynthetic microorganisms. European patent EP 001797. 2004 Sept.

[98] World Aquaculture Society [https://www.was.org/main/default asp]. Baton Rouge, LA: World Aquaculture Society, Inc.; c20012007 [updated 2008 January 11; cited 2007 September]. Available from: https://www.was.org/Meetings/AbstractData.asp?AbstractId= 10828 .

[99] Chini Zittelli G, Rodolfi L, Tredici MR. Mass cultivation of Nannochloropsis sp. in annular reactors. J Appl Phycol 2003; 15: 107 14.

[100] Chini Zittelli G, Rodolfi L, Tredici MR. In: Richmond A, Ed. Handbook of Microalgal Culture. Oxford, UK, Blackwell Science LTD; Ames, USA, Blackwell Publishing Company. 2004; 298-303.

[101] Chini Zittelli G, Rodolfi L, Biondi N, et al. Productivity and photosynthetic efficiency of outdoor cultures of Tetraselmis suecica in annular columns. Aquaculture 2006; 261: 932-43.

[102] Krichnavaruk S, Powtongsook S, Pavasant P. Enhanced productivity of Chaetoceros calcitrans in airlift photobioreactors. Bioresour Technol 2007, 98: 2123-30.

[103] Silva HJ, Cortinas T, Ertola RJ. Effect of hydrodynamic stress on Dunaliella growth. J Chem Technol Biotechnol 1987; 40: 41-9.

[104] Barbosa MJ, Albrecht M, Wijffels RH. Hydrodynamic stress and lethal events in sparged microalgae cultures. Biotechnol Bioeng 2003; 83(1): 112- 20.

[105] Sobezuk TM, Camacho FG, Grima EM, Chisti Y. Effects of agitation on the microalgae Phaeodactylum tricornutum and Porphyridium cruentum. Bioproc Biosyst Eng 2006; 28: 243-50.

[106] Spolaore P, Joannis-Cassan C, Duran E, Isambert A. Commercial applications of microalgae. J Biochem Bioeng 2006; 101(2): 87-96.

[107] Pulz O. Photobioreactors: production systems for phototrophic microorganisms. Appl Microbiol Biotechnol 2001; 57: 287-93. 